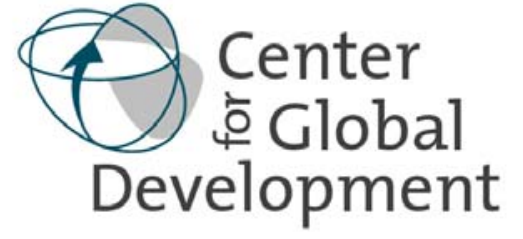

Is Africa's Skepticism of Foreign Capital Justified? Evidence from East African Firm Survey Data

By Todd J. Moss Vijaya Ramachandran. and Manju Kedia Shah

Abstract
The world has increasingly recognized that private capital has a vital role to play in economic
development. African countries have moved to liberalize the investment environment, yet have not
received much FDI. At least part of this poor performance is because of lingering skepticism
toward foreign investment, owing to historical, ideological, and political reasons. This wariness
has manifested in many ways, including a range of business environment factors that impede
greater foreign flows. Although much of the ideological resistance has faded, a number of specific
challenges to the purported benefits of FDI have been successful in preventing more active
liberalization and in moving to deal with indirect barriers. New data from firm surveys in Kenya,
Tanzania, and Uganda suggest that there are important positive effects from FDI for both the host
economies and the workers in foreign-owned firms. Based on our three-country sample, foreign
firms are more productive, bring management skills, invest more heavily in infrastructure and in
the training and health of their workers, and are more connected to global markets. At the same
time, foreign firms do not appear to succeed by grabbing market share and crowding out local
industry. These results suggest that many of the common objections to foreign investment are
exaggerated or false. Africa, by not attracting more FDI, is therefore failing to fully benefit from
the potential of foreign capital to contribute to economic development and integration with the
global economy.




\section{Is Africa's Skepticism of Foreign Capital Justified? Evidence from East African Firm Survey Data}

June 2004

Todd J. Moss, Center for Global Development

Vijaya Ramachandran, Georgetown University

Manju Kedia Shah, World Bank ${ }^{1}$

\footnotetext{
1 Todd Moss is a Research Fellow at the Center for Global Development (tmoss@cgdev.org). Vijaya Ramachandran is Assistant Professor at Georgetown University (vr9@georgetown.edu). Manju Kedia Shah is a consultant at the World Bank (mshah@mindspring.com). This paper was prepared for the Wallenberg Workshop, "The Impact of Foreign Direct Investment on Development: New Measurements, New Outcomes, New Policy Approaches," held at the Institute for International Economics on April 23, 2004. We thank Robert Lawrence and Ted Moran for helpful comments on an earlier draft and Alicia Bannon for excellent research assistance. All judgments, opinions, and errors are those of the authors alone and do not represent the views of the Center for Global Development, Georgetown University, the World Bank, or their respective staffs or boards of directors, nor the countries that the Executive Directors of the World Bank represent.
} 


\section{Introduction}

The world has increasingly recognized that private capital has a vital role to play in economic development. The UN's Millennium Declaration explicitly calls for greater foreign direct investment (FDI) to Africa. Over the course of the 1990s, African countries significantly liberalized the environment for foreign investment. Nearly all countries revised their national laws governing FDI and the vast majority lifted controls on capital (UNCTAD, 1998).

Despite these substantial changes, Africa has not received the levels of FDI that had been expected by reformers. At the same time, there remains a deeply-rooted skepticism within Africa toward foreign investment, owing to historical, ideological, and political reasons. These sentiments have manifested themselves through a range of barriers to foreign investment, including nationalization of foreign firms, heavy state intervention in the economy, direct legal restrictions on foreign investment, and a host of indirect barriers. Some of the early ideological objections to foreign capital have eroded over time and most of the legal restrictions have been removed as countries have pursued economic policy reforms over the past two decades. Nevertheless, some constraints remain in place and many of the indirect barriers remain significant obstacles to higher flows to the continent.

At least part of the lingering anti-foreign capital climate is rooted in specific concerns that purported benefits of foreign investment are not being realized. This paper outlines the context of Africa's view of foreign capital and then uses new data from firm surveys conducted in Kenya, Tanzania, and Uganda as part of the World Bank's Regional Program on Enterprise Development (RPED) to assess some of these specific concerns about the effects of FDI in poor countries.

\section{Foreign Investment in Sub-Saharan Africa}

The literature on the effects of FDI in developing countries lists a range of prospective benefits to the recipient country. At the macroeconomic level, FDI by definition brings new capital for investment, contributing to the balance of payments, adding to the country's capital stock, and potentially adding to future economic growth. FDI is also cited as a more stable type of capital flow, and thus is arguably more appropriate and development-friendly for low-income countries than portfolio flows. There is also some evidence that foreign investment can contribute to raising exports and integrating into global economic networks. At the microeconomic level there are also a range of purported benefits, especially higher productivity through new investment in physical and human capital, increased employment, enhanced management, and the transfer of technology. Foreign investment also is thought to have important spillover effects on local firms through supply and distribution chains, trading, and outsourcing (see among many, e.g., Blomström and Kokko, 1997 and 1998; Markusen and Venables, 1997).

Partly as a result of the growing recognition that FDI can play an important role in economic

growth and development, low-income countries have increasingly engaged in competition to attract foreign investment. Most low-income countries have undergone some types of policy 
reform designed to reduce barriers and attract investment and most also now have some explicit kind of investment promotion agency. Because a range of studies looking at determinants of FDI has pointed to the business environment as a key factor (e.g. Goldsborough et al, 1996; MIGA, 2002; on Africa specifically see Morisset, 2000; Pigato, 2002; Asiedu, 2003a), countries have typically undertaken to move toward macroeconomic stability, enhanced contract enforcement, and other measures thought to be investmentfriendly.

Africa has also been part of this trend. Many countries have taken steps to liberalize the environment for FDI, gradually allowing foreign investors to operate in increasing types of sectors. Indeed, whereas countries used to list those specific sectors open to foreigner investment, the norm is now to assume a legally open regime with restricted sectors listed as the exceptions. There have also been some policies actively designed to attract investment, such as tax holidays, easing of import and customs controls, infrastructure investment, and labor law reform.

The response to Africa's investment policy changes has been mixed. Inward FDI to Africa has been marked by three general trends over the past three decades. First, levels have generally increased over time in nominal absolute terms. Average annual flows in the 1970s to sub-Saharan Africa averaged just $\$ 907$ million. In the 1980 s, this figure rose only slightly to $\$ 1.3$ billion, but jumped to $\$ 4.3$ billion in the 1990s. In the most recent three years (200002 ), the average inward FDI to sub-Saharan Africa has more than doubled again to $\$ 9.3$ billion per year.

Despite these increases, total world FDI has grown much faster. As a result, Africa's relative share of global FDI, which averaged around 5 percent in the early 1970s, fell to 1-2 percent by the early 1980s - and has not recovered above this level (see Figure 1). This loss in FDI share has coincided with other developing regions attracting much higher levels of FDI, also pushing down Africa's relative share. Africa's proportion of all FDI to developing countries has followed a similar trend, plummeting in the late 1970s from above 20 percent to around 5 percent and hovering near or below that level for the past two decades. In 2002, it was still 5 percent. 
Figure 1: FDI to Africa ${ }^{2}$

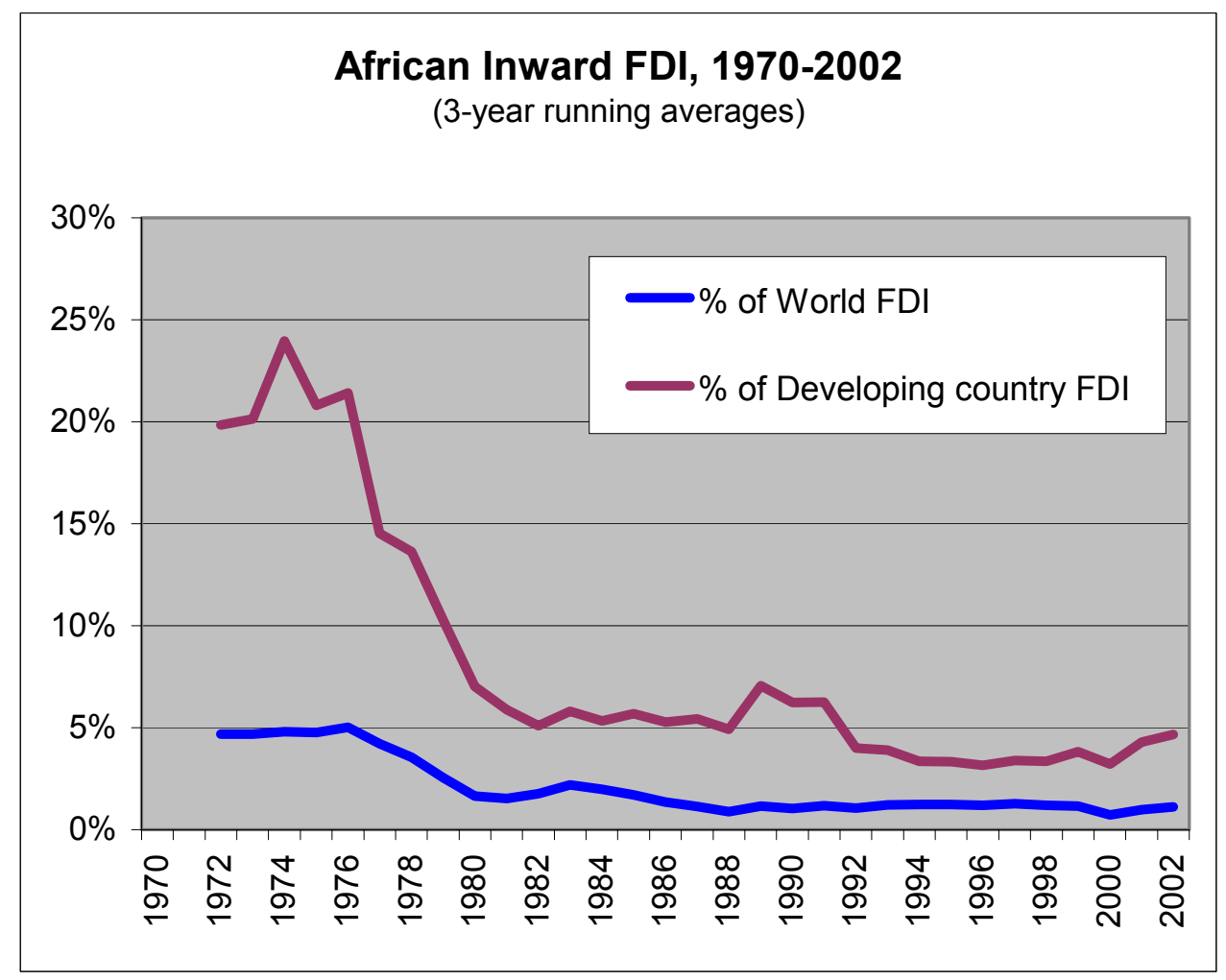

Source: UNCTAD FDI database

The third trend is strong concentration in a few countries. In the most recent 5-year period, just three countries (South Africa, Angola, and Nigeria) accounted for 55 percent of the total (Table 1). The top fifth (10 out of 48 countries) account for 80 percent, and the bottom half account for less than 5 percent. This trend has held for at least the last three decades, with the top 10 countries accounting for more than 75 percent of the continent's total FDI inflows. Additionally, there has been a long-standing concentration in the extractive sectors, particularly petroleum. Nearly all of the investment going to Angola, Nigeria, Equatorial Guinea, Sudan, and Chad is oil-related, with the bulk of the investment in the former three invested in offshore facilities. In the most recent 5-year period, these five countries accounted for 43.5 percent of Africa's total FDI (roughly matching oil-concentration in previous periods). In addition, much of the foreign investment in Ghana, Zambia, Namibia, Botswana, and South Africa, and more recently Tanzania, has been in large mining projects.

\footnotetext{
${ }^{2}$ These figures are based on totaling 48 Sub-Saharan Africa country figures and thus are not the same as UNCTAD's reported "Africa" aggregate total, which includes North African countries. Sudan is considered here to be sub-Saharan.
} 
Table 1: Inward FDI: Sub-Saharan Africa, 1998-2002

(Average annual)

\begin{tabular}{l|llll}
\hline & & & & \\
Rank & & Net flows $(\$ m)$ & percent SSA totalCumulative \% \\
\hline 1 & South Africa & 2099 & 24.1 & 24.1 \\
$\mathbf{2}$ & Angola & $\mathbf{1 5 8 4}$ & $\mathbf{1 8 . 2}$ & 42.4 \\
$\mathbf{3}$ & Nigeria & $\mathbf{1 0 7 4}$ & $\mathbf{1 2 . 4}$ & 54.7 \\
$\mathbf{4}$ & Sudan & $\mathbf{4 7 8}$ & $\mathbf{5 . 5}$ & 60.2 \\
$\mathbf{5}$ & Equatorial Guinea & $\mathbf{3 8 4}$ & $\mathbf{4 . 4}$ & 64.6 \\
6 & Tanzania & 344 & 4.0 & 68.6 \\
7 & Mozambique & 283 & 3.3 & 71.8 \\
$\mathbf{8}$ & Chad & $\mathbf{2 6 6}$ & 3.1 & 74.9 \\
9 & Côte d'Ivoire & 260 & 3.0 & 77.9 \\
10 & Uganda & 238 & 2.7 & 80.6 \\
-- & & & & \\
21 & Kenya & 62 & 0.7 & 95.0 \\
$22-48$ & Bottom 27 countries & 433 & 5.0 & 100.0 \\
\hline
\end{tabular}

Bold is mainly oil-related; Chad data is based on 4-year average because of missing data for 2001.

Source: UNCTAD FDI Database, author's calculations

For our purposes here, the oil and mining investment concentration is relevant in two ways. A large portion of FDI to Africa has been in enclave projects, which may limit their integration with local firms and the local economy. At the same time, this isolation means these projects are typically better able to avoid some of the barriers to foreign investment, especially security issues or infrastructure weaknesses. The large size of foreign oil and mining firms also means that they are often able to negotiate directly with the government, and thus may be able to avoid bureaucratic bottlenecks or other regulations that might affect smaller enterprises or those integrated into the local economy. This suggests that nonextractive FDI, especially those in smaller firms in manufacturing or services face a very different environment.

\section{African skepticism toward foreign investment}

Despite the growing competition for FDI and Africa's ability to attract only modest amounts outside of the extractive industries, the continent still has a strong historical skepticism toward foreign capital. Much of the prevailing attitude toward foreign investment is rooted in history, ideology, and the politics of the post-independence period. There is also a set of specific concerns that the benefits to FDI are not forthcoming and that certain kinds of government intervention are necessary to correct market failures. This discussion will lead directly to some of the outcomes of these attitudes - the direct and indirect barriers to FDIin the following section.

Africa's early experiences with foreign companies continue to affect official and public perceptions of FDI. The arrival of European capitalism in West Africa, first by the 
Portuguese in the $15^{\text {th }}$ century, and later by the Dutch, French and British, is indelibly linked in the public mind to the slave trade and as a precursor for colonialism. The use of European companies as proxies for the sovereign has helped to link in the public's mind international business with imperial expansion. In 1652 Jan van Riebeeck arrived in the Cape on behalf of the Dutch East India Company. In the late $19^{\text {th }}$ century, Cecil Rhodes claimed swathes of southern Africa on behalf of the British South Africa Company. Through the company, Rhodes secured mining concessions in gold, copper, and diamonds, playing the dual roles of entrepreneur and representative of the British crown. Harsh conditions and treatment of laborers added to the linking of foreign companies and exploitation, such as in the mines (e.g., under the Witwatersrand Native Labor Association) or plantations (see e.g., Hochschild, 1999 for conditions on rubber plantations in the Belgian Congo). As with the United Fruit Company in Latin America, foreign companies in Africa are frequently thought of as agents of imperialism and exploitation.

Although the colonial period ended more than a generation ago, it has also remained a central factor in Africa's skepticism over joining the global economy. Reflecting a common sentiment even today, Zambia's leading daily recently editorialized:

Since when has global capitalism been concerned about equality, fairness and genuine justice or the lives of those it affected? From the days of mercantile capitalism and its slave trade, through classical colonialism with its crude extraction of raw materials from our countries, to today's neo-colonialism the situation of our people is basically or fundamentally the same-marginalised, exploited, ignorant, diseased, hungry and generally poor (The Post, April 26, 2003)

Second, perhaps just an importantly, most of Africa's anti-colonial movements were heavily supported by the Soviet Union and its satellites. This encouraged the popularity of socialism and an ideological bias against foreign (or, more specifically, Western) capital. This was closely complemented by dependency theory, which argued that capitalism in general, and foreign companies in particular, were agents of underdevelopment and merely continuing colonialism in another guise (Leys, 1975; Senghaas-Knobloch, 1975; Rodney, 1981). Although dependency theory has been widely discredited, it continues to flourish among certain academic circles, many NGOs, and in some political circles today and contributes to the current climate of distrust of foreign investors.

Although there has been substantial turnover of political leadership in Africa over the past decade, many of the current decision-makers (including those frequently hailed as reformers) have held political positions for decades and were trained on the socialist model steeped in anti-foreign investment ideology. Indeed, nearly every African leader, no matter how liberal he is considered today, began his career as a socialist or Marxist. Even as most of Africa's finance ministers have become increasingly convinced that economic openness can be beneficial for their countries and fluent in the language of international capitalism, many of their cabinet colleagues remain unreconstructed economic nationalists. Some of the ideological opposition to foreign investment is part of a general critique of capitalism - and more recently of globalization - and foreign capital remains an easy target. 
Third, ideas of economic nationalism affected sentiment towards foreign investment, and they continue to influence policy today. Kenneth Kaunda's "political independence is meaningless without economic independence," shaped not only Zambian investment policy but also those of his entire generation of leaders (Tangri, 1999; see also Kaunda, 1979). Botswana, one of the African countries that has pursued more orthodox economic policies, has not been immune. Kenneth Koma, leader of the opposition, recently cautioned against privatization because, "...lack of managerial skills and capital among Batswana will lead to a situation where the economy will be in the hands of foreigners which will ultimately impact on the policy of the country...It is like a man who marries a rich woman. He will lose control over the affairs of his house" (quoted in Mmegi, March 5, 2000).

On the one hand leaders frequently sought a symbolic break with foreign players that were closely identified with colonialism or external control. On a more practical level, political elites also did not want to be constrained by foreigners who might control key strategic sectors of the economy or their access to foreign exchange. Although FDI may be considered more stable than other types of capital flows, the flip-side is that foreign investors with a greater stake in the long-term might be more inclined to get involved in influencing policy or, in the extreme, supporting opposition political groups. ${ }^{3}$

Tangri (1999), aptly summarizes the political underpinnings:

Strong feelings of 'economic nationalism' stemmed from the weakness and subordinate status of African private enterprise as well as from the fact that African economies at independence were largely in the hands of foreigners. Public sector enterprise was seen as enabling the state to carry out the activities that African private entrepreneurs could not perform and also to reduce the dominance of foreign enterprise. Throughout the continent, political leaders sought to secure greater indigenous ownership of the economy, especially of the activities a country depended on for its foreignexchange earnings. They also sought to achieve greater local control of the economy, particularly to ensure that economic decisions were consonant with governmental interests. Foreign economic control posed constraints on state personnel exercising decisions affecting the economy; it also made the possibility of foreigners intervening in domestic politics much more likely. On nationalistic and political grounds, therefore, government leaders desired economic independence (pp 19-20).

Fourth, many of the purported benefits of FDI are frequently challenged directly, both on ideological and empirical grounds. There is a common critique that foreign investors crowd out local firms that cannot compete because of size, financing, marketing power, or some

\footnotetext{
${ }^{3}$ Tangri (1992) shows that this dynamic could under certain circumstances work in the opposite way. Under Jerry Rawlings (1981-2000), the government in Ghana was less suspicious of foreign business than it was of domestic business, which had been closely aligned with the main opposition party. Despite Rawlings' populist streak, his policies were an example of bias toward foreign investors over local ones as the former were seen as less likely to be involved in domestic politics.
} 
other unfair advantage (Dunning, 1993; ActionAid, 2003). The government-owned Times of Zambia, for example, recently argued, "The uneven playing field has led to local industry and products failing to compete effectively ...there are far too many cases of investors coming into the country and divert into ventures that should be best left to the locals....It is such issues that investment legislation needs to address" (March 4, 2004).

There are complaints that foreign firms merely exploit local labor and make no contribution to the wider economy, either through creating jobs, training workers, or in using local suppliers (Oxfam, 2003b). A frequent grievance against foreign investment is that, although the theory suggests capital inflows, in practice FDI can be a drain on foreign exchange. This is because foreign firms may be more likely to import materials (Chudnovsky and Lopez, 2000) and that foreign firms may remit profits (Oxfam, 2003a). More broadly, there is considerable concern that the interests of foreign firms will diverge from social development objectives or constrain governments' ability to promote economic development (Chudnovsky and Lopez, 2002; South Center, 1997; Kolodner, 1994). ${ }^{4}$

\section{African Barriers to FDI}

As a direct result of these historical and political issues, African governments have constructed a series of barriers to foreign entry. The notion that Africans needed to seize control of their economies after independence manifested themselves in several ways that continue to affect foreign investment. Even though early concerns were directed at large European and small South Asian investors ${ }^{5}$, the more recent influx of investment from East Asian (Brautigam, 2003) and South African investors (Daniel, et al, 2003) has helped to sustain some of these issues.

Economic nationalism was used to justify extensive state intervention in the economy, including the creation of parastatals, heavy regulation, and often nationalization or expropriation (Kobrin, 1984). Although these affected both local and foreign firms, many of the largest exporting firms had been foreign owned and operated and intervention was directly targeted at them. Many of the nationalized companies have of course since returned to foreign private ownership, such as Ghana's Ashanti Goldfields and the Tanzania Cigarette Company which were both nationalized in the 1960s and then privatized in the mid 1990s (although governments retain substantial minority stakes in each). Nevertheless, the threat of expropriation remains ever-present. As we will argue below, even where privatization has been actively pursued, governments have also tended to continue to play a strong interventionist role in the economy, impacting the business environment in direct and indirect ways.

\footnotetext{
${ }^{4}$ Two other common criticisms of FDI not addressed here are the impact on environmental management and indigenous people (e.g., see Oxfam, 2003a). See Grabel (1995) for an attack on portfolio investment for constraining the ability of governments to set national priorities and Moss (2003, Chapter 6) for a rebuttal.

${ }^{5}$ Throughout East Africa many Africans of Asian descent are still considered "foreigners" and when officials speak of "foreign capital", they are at times referring to minority local investors (Himbara, 1993). There is a large literature on minority entrepreneurs in Africa (e.g., Winder, 1962; Brennan, 1999; Mengistae, 2001; Vandenberg, 2003; in the popular press see Sowell, 1992; Kotkin, 1994). Although many of the measures taken or biases against foreigners are also directed at minority groups, for the purposes of this paper "foreign" is considered a citizenship rather than racial issue.
} 
Second, there was, and in many countries continues to be, a deliberate policy of Africanization, whereby state intervention is justified in order to transfer ownership of firms from foreigners (or indigenous minorities) to locals (e.g., Adedeji, 1981; Boone, 1993). In its most extreme cases this can be accomplished through widespread and violent expropriation, such as Uganda under Idi Amin or more recently commercial farms in Zimbabwe. But many countries, including Kenya and Zambia, pursued less violent but nonetheless explicit forms of encouraging ownership transfer to locals. This policy continues in some forms today, especially with privatization, which tends to include special dispensations to encourage local ownership through legal biases or awarding bids or through share set-asides or discounts (Craig, 2002).

Third, there are direct de jure barriers to foreign participation in the economy. Explicit legal restrictions on foreigners have diminished substantially as economic reform and liberalization has been implemented, but some limitations still exist. Most obviously, most African stock markets have legal limits on the amount of equity owned by non-resident foreigners (Moss, 2003). Although this mostly affects portfolio investors, any share above 10 percent is considered FDI, so this is a direct limitation for any publicly listed company and a potential reason not to list on the local exchange.

Many African countries still have restricted sectors in which foreigners are not allowed to own businesses. In some cases, this is tied directly to parastatal monopolies, so liberalization has occurred alongside privatization, but not always. Ethiopia legally excludes foreigners from the financial sector, and Tanzania only allowed foreign bank entry since the early 1990s. Ghana, which has undergone significant liberalization since beginning economic reform two decades ago, still bars foreigners from certain trading and services sectors.

Many countries have legal requirements for (or have given officials wide discretionary powers to add) performance requirements, such as local employment, local partnership or local inputs. Concerns over protecting these conditions led to considerable African (and NGO) resistance to reforms aimed at universalizing national treatment or limiting the ability to impose certain requirements, such as the Multilateral Agreement on Investment and more recently at the WTO (Graham, 2000). Oxfam, for example, claims that a WTO agreement on investment could be "disastrous" (2003a). ActionAid (2003) also warns against including investment in multilateral trade negotiations because, "Developing countries need to regulate investment in order to protect sensitive sectors from liberalisation and to maximise the positive benefits for poor people. Yet it is precisely these measures which would be threatened by a WTO investment agreement because host governments would be restricted in their ability to regulate in favour of the poor." The overall effect is that, despite the trend of investment liberalization and privatization throughout much of Africa, there are still substantial lingering legal biases against foreign investment in many countries.

Lastly, and perhaps most importantly, there are a range of indirect obstacles related to the business climate that acts as de facto barriers to FDI. ${ }^{6}$ Morisset (2000) and Basu and

${ }^{6}$ There is a rich literature on the determinants of FDI, looking at a range of variables, such as income, infrastructure, labor costs, taxes, openness, and political stability. Singh and Jun (1995), for example, find that 
Srinivasan (2002) found that certain African countries have been able to attract FDI, not because of natural resources, but through a broad improvement in the business environment and deliberate image-enhancing campaigns. ${ }^{7}$ Although most African countries have undertaken substantial economic reform, Asiedu (2003b) finds that the decline in African FDI as a ratio of total FDI is partly because improvements in policy environment have not been large relative to reforms in other regions. In addition, Africa has been especially prone to "partial reform syndrome", where many reforms are only partially implemented or where only parts of a basket of policy changes are pursued, undermining the intended effect (Gordon, 1993; van de Walle, 2001).

Indirect barriers typically include bureaucratic and other informal impediments to foreign investment, such as ambiguous regulatory approval, delays in customs clearance, visas for expatriate workers, or weaknesses in the legal system. Many of these barriers are captured in the broader business climate, affect domestic firms as well, and could be considered unintentional. However, these factors are different for foreign firms in two important ways. Data from the RPED investment climate assessments suggest that foreign firms face dissimilar environmental constraints than domestic firms (see below), which implies that public policy actions to remedy these problems could be inherently biased for or against foreign firms.

Critically, it is also not always clear that such barriers are in fact unintentional, but rather are used as deliberate impediments to foreign entry or operation. Political economists have frequently found that excess bureaucracy, erratic economic policy, and other problems associated with weak business environments have strong political logic (Bates, 1981; Lewis, 1996; Chabal and Daloz, 1999; van de Walle, 2001). Because political elites and business elites are typically allied in Africa (or, often, are one in the same), foreign investors could threaten market positions of privileged domestic firms. Indeed, inefficient industries and policies have often been a good source of rents for the state or for particular individuals. Monopolistic positions by influential businessmen, political leaders, or their families are frequently threatened by foreign competition. Much of the nationalist resistance to liberalization, including worries of foreign domination or the displacement of local firms, has narrow rent-seeking roots, designed to benefit certain people or groups. In this way, clearance of investment projects may be rejected out of the "national interest" or imported equipment may be inexplicably delayed or lost, but in practice this is used to protect politically connected competitors. Tangri concludes, “...the political nature of the stateforeign business relations is an important reason why sub-Saharan Africa has failed to attract much foreign direct investment since independence." (1999, p. 14)

export-orientation is a large attraction for FDI. Goldsborough et al (1996) emphasize macroeconomic stability and reforms. For an overview of the various studies that use cross-country regressions to identify country characteristics, see Table 3 in Asiedu (2001).

${ }^{7}$ Morisset found this was true for Mali and Mozambique. Basu and Srinivasan found this for Mozambique and Uganda. 


\section{Foreign Investment in East Africa: Background}

Given this context, we turn now to three cases studies in East Africa: Kenya, Tanzania, and Uganda. Each of these countries has seen a recent improvement in FDI flows (see Figure 2) and each is undergoing some process of policy reform and liberalization. None has any meaningful oil-related foreign investment, but Tanzania's recent inflow surge has been largely driven by greenfield investment in its rapidly growing gold mining sector.

\section{Figure 2: FDI to East Africa}

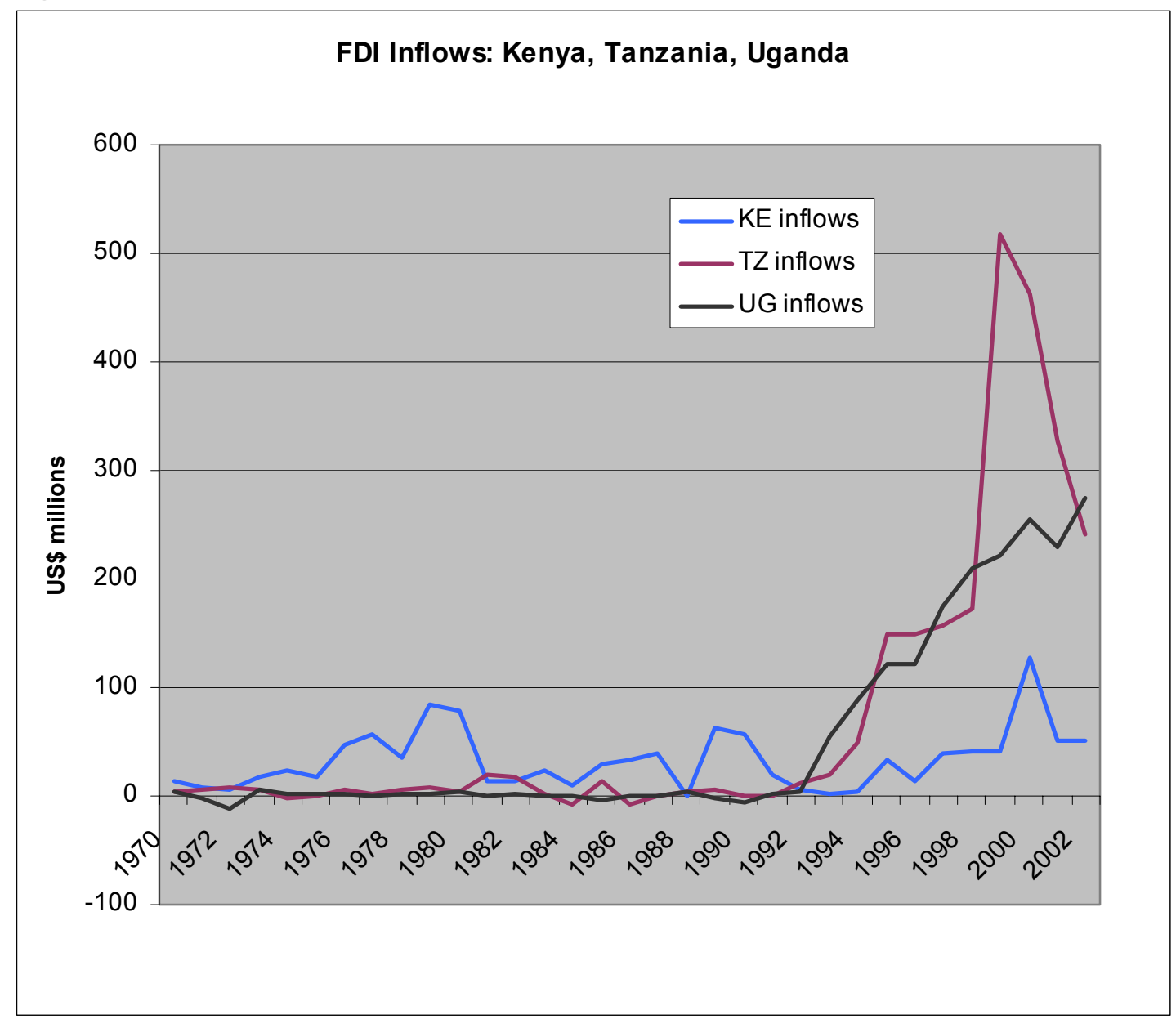

Source: UNCTAD FDI database

Each of the three countries has been substantially affected by its colonial experience and suffered post-independence traumas of some kind that affect their present attitudes toward foreign investment. All three are former British colonies, although mainland Tanzania was German prior to World War I. Kenya was designated a settler colony and had a substantial European business and farmer class, whereas Tanzania and Uganda were managed under indirect colonial rule and thus had smaller European populations. All three countries have significant populations of South Asian origin that date to the colonial period. 
Kenya. After independence, Kenya chose to align with the West in the Cold War. Although ostensibly allied with market capitalism, in practice the government followed a statist strategy that increasingly deteriorated into narrow rent-seeking and corruption. Partially because of the large colonial settler population, there was a substantial foreign presence in the country, much of which remained after independence. Large foreign banks, for instance, have continued operations. For the most part, legal barriers to foreigner investment have been minimal. Kenya officially encourages foreign investment and grants national treatment to foreign investors (WTO, 2000). Nevertheless, Kenya's political elites believed "reliance on external actors was...potentially unreliable, economically risky, and most importantly, politically unacceptable" (Himbara, 1994, p. 470). The government therefore used state enterprises to deliberately promote African entrepreneurs at the expense of both foreign and local Asian investors (Jaffee, 1992; Himbara, 1993, 1994; Holmquist, 2002). At times antiforeigner sentiment, fuelled by government officials, led to violence, including widespread looting of Asian-owned businesses in the early 1980s. There are also legal restrictions on equity investors, with foreign investors capped at 40 percent of Nairobi stock exchange listed companies.

More broadly, there has been wide regulatory discretion, with significant informal biases against foreign firms and minority-owned firms. Over time, the deteriorating business environment, especially poor governance, growing corruption, and more recently crime, has contributed substantially to low inflows of FDI. Despite its western-orientation and rhetorical commitment to capitalism, Kenya has not been immune to some of the nationalistpopulist arguments against foreign investors. Parliamentarian Stephen Ndicho, waving a copy of the constitution, recently declared, "This document says Kenya is a sovereign state, but we are not and we now live at the mercy of these multinationals" (quoted in The Nation, December 7, 2000). Another MP Mirugi Kariuki recently implored the government to "chase away any investor who perceives Kenya as a place where cheap labor is available and whose intention is to exploit workers with impunity" (quoted in The Monitor, June 26, 2003).

Kenya's current business environment is in flux following the defeat of KANU in December 2002 , ending its nearly four decades in power. The new government of President Mwai Kibaki is thought to be reformist, and ran on an anti-corruption platform. In theory, this should benefit foreign investors as the government tackles one of the most prominent barriers to greater inflows. However, the new ruling coalition also has its anti-foreigner tendencies. In the late 1960s Kenya's official campaign of discriminating against Asian businessmen in favor of indigenous Africans was led by a then-obscure commerce minister, Mwai Kibaki (Himbara, 1994). Raila Odinga - currently a cabinet minister, but also a possible successor to Kibaki and the leading candidate to become prime minister if proposed constitutional changes are implemented-has anti-FDI leanings. In 1999, he suggested that Kenya was receiving too much FDI rather than too little, claiming, "the government must protect local industries against undue competition from multinationals to speed up industrialization... no country could industrialize with foreign investment alone" (quoted in The Nation April 22, 1999).

Tanzania. Tanzania under Julius Nyerere attempted a socialist transformation that saw widespread nationalization of property, including the seizure of foreign assets. Foreign 
investment was legally and effectively banned. This was widened in the 1970s to include most Asian-owned businesses and an (unevenly enforced) expropriation of any property valued at greater than $\$ 15,000$. Capitalism and foreign capital in particular were considered un-African, whereas ujamaa was considered more "authentic" and appropriate. ${ }^{8}$

More recently the climate has changed considerably. Economic reforms began slowly in 1986, and accelerated after an economic crisis in the mid 1990s, substantially altering the government's stance on foreign investment. The privatization program, which included many nationalized firms previously owned by foreign companies, facilitated the return of foreign firms back into the country. Mining reforms in the early 1990s allowed major new investment by foreign firms, especially Ghana's Ashanti Goldfields and South Africa's AngloGold. Foreign banks were allowed entry after 1993 and several large South African and British banks began operations soon thereafter. Legal changes in 1997 lifted most of the remaining sectoral restrictions on foreign investment on the mainland (although many regulations remain in place in semi-autonomous Zanzibar). Previous demands of government equity have also been lifted for all sectors, except for petroleum (UNCTAD, 2002). Otherwise, foreign investors are mostly afforded national treatment, including protection of fiscal incentives, guarantee of repatriation, and importation of expatriate staff. Remaining legal biases are relatively minor, such as the minimum capital investment to qualify for approval is three times the local requirement.

Despite the reforms and increased inflows, there is residual resentment against foreign capital. For Tanzania we have specific evidence of skepticism toward foreign capital. Solid polling data on such attitudes is unusual in Africa, but a poll conducted by Michigan State University in 2001 asked specifically about whether the government should encourage foreign investment or "be wary of foreigners because they may gain control of our national wealth". Two-thirds felt the latter, with $57 \%$ strongly so; just $23 \%$ strongly agreed that government should encourage foreign investment (Afrobarometer, 2003). ${ }^{9}$

Other indicators of attitude toward foreign capital also suggest doubt. The stock exchange operated for its first three years with a complete ban on foreign participation. Only in 2003 did it allow non-resident foreigner to buy shares, and only up to 60 percent of total equity. Africanization continues officially, although implementation has been piecemeal. The privatization program did not overtly penalize foreign firm bids, but there were special financing terms for local investors buying smaller firms. Although there are no blanket legal requirements for local partners, officials have hinted that such a provision was possible. Iddi Simba, then Minister for Trade and Commerce, said, "Foreign companies which want to invest in Tanzania will be compelled to identify local partners. If they cannot do so, the government will help them identify partners because we are now aiming at localising and

\footnotetext{
${ }^{8}$ The closest translation of the Swahili word ujamaa is "family", but Nyerere and others used it as a synonym for his concept of "African socialism".

${ }^{9}$ The Afrobarometer is a joint project of The Institute for Democracy in South Africa, Ghana Centre for Democratic Development, and Michigan State University, which polls attitudes on democracy and markets in Africa. They polled in Uganda in 2000, but did not include this specific question on foreign investors. They have not polled in Kenya. Aggregate data for 12 countries is scheduled for release later in 2004.
} 
promoting local participation in investments." (quoted in The East African, February 18, 1999).

On the business environment, bureaucracy also remains a problem. Most of the current officials and bureaucrats were trained during socialist times and the reflex has been to overregulate and resist ceding control. For example, one privatized manufacturing firm was under investigation after it tried to lease some of its space because its business plan did not include real estate transactions (Temu and Due, 1998). The Tanzanian public has also retained some of its old reservations. Despite the large inflows of mining investment, even the business press has complained. For example, the Business Times recently asked:

... what is the percentage of the so-called 'economic contribution' of the mining companies to Tanzania vis-à-vis what they are reaping from their operations under decidedly lopsided agreements? True, the sector has grown rapidly since 1997. But, for whom has it been growing, pray? How much has Tanzania as a nation-state, and its impoverished people, gained from that growth? ... it is an officially sanctioned rape of Tanzania's mineral wealth (September 26, 2003).

Uganda. Uganda has seen the most extreme swings in sentiment toward foreigners. Idi Amin nationalized foreign businesses and in 1972 forcibly expelled 80,000 Asians. His successor Milton Obote was little better. However, the government of Yoweri Museveni, which came to power in 1986, began one of Africa's most wide-ranging economic reform programs, re-opening the economy to foreign investment. In the 1990s Museveni actively sought foreign investment and successfully invited Asians back to the country to reclaim lost property.

Ironically, Uganda's investment code is technically restrictive on foreigners, insisting on a license that could be denied for any number of ambiguous reasons, including anything deemed "contrary to the interests of Uganda". In practice, however, the licensing process has become automatic and the national interest clause has never been formally invoked against a prospective foreign investor (UNCTAD, 2000). The only restricted sector is agriculture, although agro-processing has been allowed and the cabinet has approved some exceptions in the case of foreign investment in tea estates. Privatization has also encouraged foreign investment in a range of sectors. Uganda opened a stock market in 1999 with no restrictions of any kind on foreigners.

Despite the general openness in Uganda, performance requirements can be imposed on foreigners. For any business majority-owned by foreigners, officials have legal rights to impose employment, local input, or technology conditions on the license. There are also minor biases against foreign firms in finance as the central bank may impose restrictions on access to domestic credit, and foreign-owned banks and insurance companies are subject to higher capital requirements. Foreign investors are also allowed leasehold on land, but are not permitted freehold land title. 


\section{Foreign Investment in East Africa: New Results from Firm Surveys}

In this context, the results of a new firm-level investment climate database from the World Bank's Regional Program on Enterprise Development (RPED) are illuminating. The firm surveys, which cover between 300 and 400 manufacturing firms of various size, classes, and types of ownership in Kenya, Tanzania, and Uganda, were undertaken during the period 2002-03. A series of variables describe various characteristics of firms including the inputs and outputs of the production process, access to finance, wages and other characteristics of workers, and types of technology and learning in the firm. The surveys also measure the amount of foreign equity in each firm surveyed. ${ }^{10}$ Two key results emerge: (a) foreign firms often operate in a very difficult business environment and (b) despite the obstacles they face, they are more productive and invest more in the production than do domestic firms. The overall results suggest that foreign direct investment brings many of the claimed benefits, including some of those specifically challenged by critics.

Let us begin by looking at the business environment that faces firms operating in Uganda, Kenya, and Tanzania. We see that both foreign and domestic firms face several constraints that impede their day-to-day operations (Table 2). Apart from the somewhat predictable complaints about the cost of finance and tax rates, firms complain about macroeconomic instability, the availability of reliable electric power, corruption, tax administration, and crime. A higher proportion of foreign firms complain about corruption in all three countries, suggesting that foreign firms bear a greater burden of non-official payments, or at least are more sensitive to their prevalence.

\footnotetext{
${ }^{10}$ The World Bank's Regional Program on Enterprise Development, based in the Africa Private Sector Group, has conducted firm-level surveys in Africa for over a decade. In recent years, a new round of African data has been collected as part of the Bank-wide Investment Climate Initiative. In the past two years, firm surveys have been conducted in Mozambique, Eritrea, Kenya, Tanzania, Uganda, and Zambia. Surveys are currently underway in South Africa, Lesotho, Mauritius, Madagascar, Senegal and Mali. More information on these surveys and the survey methodology is available at www.worldbank.org/rped or www.worldbank.org/privatesector.
} 
Table 2: Business Environment in East Africa

\begin{tabular}{|c|c|c|c|c|c|c|}
\hline \multicolumn{7}{|c|}{$\begin{array}{l}\text { Respondents' Evaluation of General Constraints to Operation } \\
\% \text { of firms evaluating constraint as "major" or "very severe" }\end{array}$} \\
\hline & \multicolumn{2}{|l|}{ Uganda } & \multicolumn{2}{|l|}{ Tanzania } & \multicolumn{2}{|l|}{ Kenya } \\
\hline & Foreign & Domestic & Foreign & Domestic & Foreign & Domestic \\
\hline Corruption & 55 & 33 & 58 & 50 & 81 & 72 \\
\hline Macroeconomic Instability & 58 & 41 & 51 & 41 & 49 & 52 \\
\hline Regulatory Policy Uncertainty & 38 & 24 & 27 & 33 & 60 & 52 \\
\hline Customs and Trade Regulations & 38 & 23 & 36 & 30 & 45 & 41 \\
\hline Crime, theft and disorder & 37 & 24 & 18 & 27 & 73 & 71 \\
\hline Access to Land & 25 & 16 & 18 & 26 & 23 & 24 \\
\hline Tax administration & 42 & 35 & 58 & 55 & 47 & 53 \\
\hline Electricity & 49 & 43 & 67 & 57 & 53 & 47 \\
\hline Anti-competitive or informal practices & 34 & 30 & 29 & 23 & 72 & 62 \\
\hline Telecommunications & 6 & 5 & 11 & 12 & 67 & 40 \\
\hline Transportation & 29 & 21 & 24 & 22 & 54 & 38 \\
\hline Cost of Financing (e.g. interest rates) & 54 & 62 & 48 & 60 & 66 & 77 \\
\hline Tax rates & 43 & 50 & 78 & 72 & 55 & 69 \\
\hline Access to Financing (e.g. collateral) & 37 & 48 & 35 & 52 & 36 & 49 \\
\hline Skills \& Education of Available Workers & 25 & 32 & 24 & 25 & 31 & 27 \\
\hline Labor Regulations & 12 & 10 & 22 & 10 & 17 & 24 \\
\hline Business Licensing \& Operating Permits & 13 & 9 & 22 & 28 & 13 & 17 \\
\hline
\end{tabular}

Looking at the case of Uganda in more detail, the uncertainty in the business environment is of concern to both local and foreign-owned firms. Corruption is of greater concern to foreign firms; they pay almost 4 percent of revenues in informal payments compared to less than 2 percent for domestic firms (Table 3). The data indicate that between 4 and 20 percent of respondents make a nonofficial payment for telephone connections, electrical connections, construction permits, and import and trading licenses. Finally, it is interesting to note that foreign firms are able to compensate to a greater extent for poor services than local firms (Table 4). Both foreign and domestic firms experienced about 40 power outages in the year preceding the survey. However, foreign firms are able to offset these losses to some extent. About 68 percent of foreign firms have their own generators and 28 percent have a well, compared to 26 percent and 9 percent respectively for domestic firms. 
Table 3: Corruption in Uganda

(all percentages as reported by respondents)

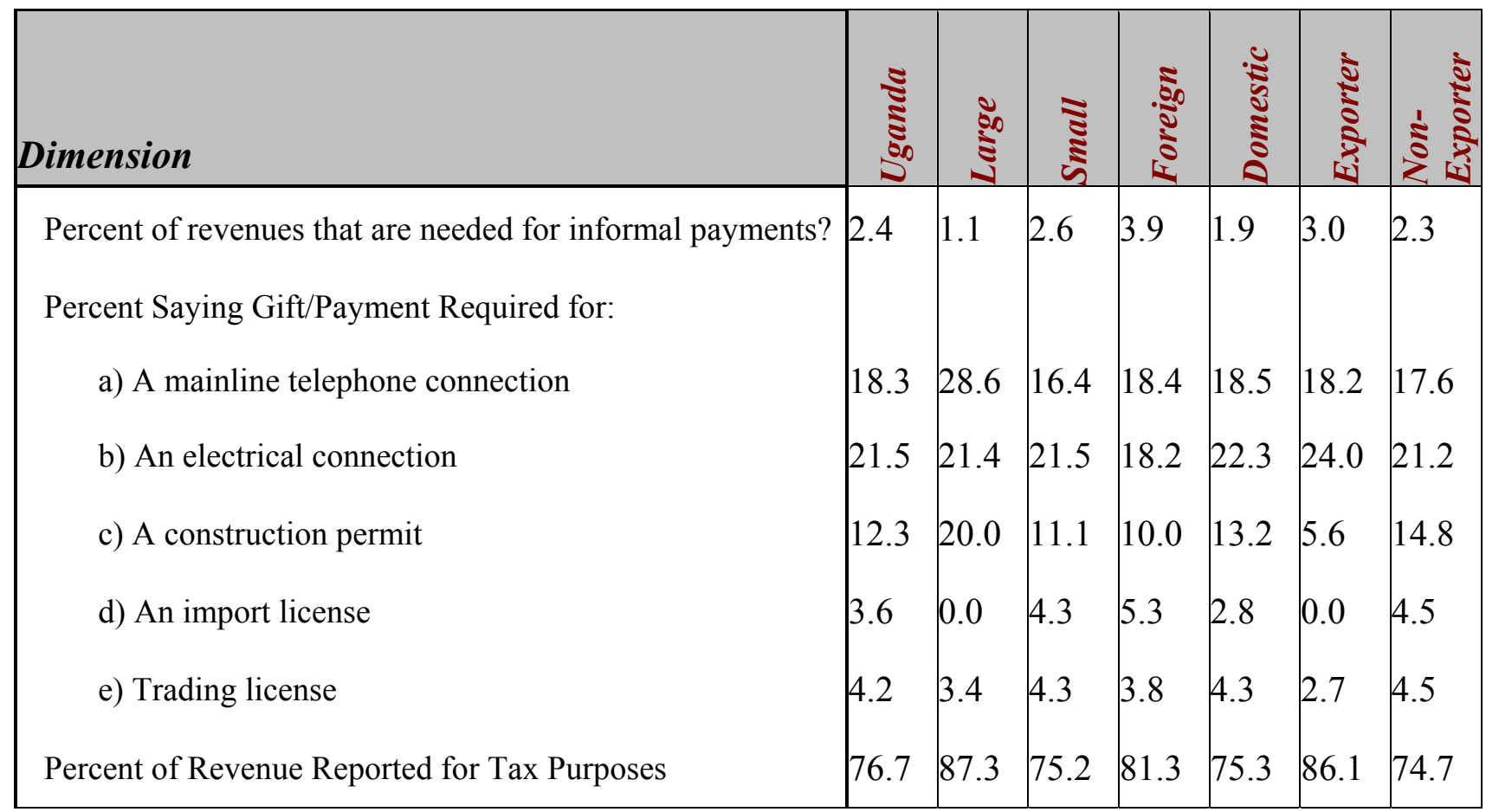

Source: World Bank (2004)

Table 4: Infrastructure Indicators in Uganda

\begin{tabular}{|c|c|c|c|c|c|c|c|}
\hline & $\begin{array}{l}5 \\
5 \\
5 \\
5 \\
5 \\
5\end{array}$ & 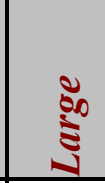 & 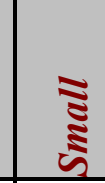 & 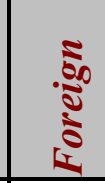 & 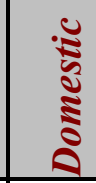 & 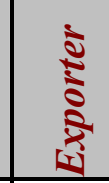 & نั้ \\
\hline Freq of power outages(times last yr) & 38.6 & 54.2 & 36.5 & 40.3 & 38.0 & 38.3 & 37.7 \\
\hline$\%$ of production lost due to power outages & 6.3 & 4.5 & 6.5 & 7.4 & 5.9 & 3.7 & 6.7 \\
\hline Have own generator $(\%)$ & 35.3 & 69.4 & 30.7 & 67.7 & 26.0 & 53.3 & 31.9 \\
\hline Have built own well (\%) & 13.0 & 30.6 & 10.6 & 27.9 & 8.7 & 24.4 & 10.6 \\
\hline No. of days to obtain a telephone connection & 33.2 & 23.1 & 35.1 & 17.7 & 39.3 & 35.1 & 32.8 \\
\hline $\begin{array}{l}\text { No. of days to obtain an electricity } \\
\text { connection }\end{array}$ & 38.3 & 39.1 & 38.3 & 46.8 & 36.2 & 48.7 & 36.6 \\
\hline
\end{tabular}

Source: World Bank (2004) 
Table 5 describes the regulatory burden and administrative delays that firms face in Uganda. Again, it is clear that both foreign and domestic firms operate in a very difficult business environment. Only 40 percent of firms in Uganda report that regulations are interpreted in a consistent and predictable manner. Almost 4 percent of foreign firms report that payments are made to "get things done" compared to 2 percent of local firms; it can be argued that these estimates are downward biased but that the differential between foreign and domestic firms is likely accurate. Foreign firms also spend significantly more time on inspections and meetings with officials ( 26 days per year versus 9.7 for local firms), yet report a higher percentage of their revenues for tax purposes.

Table 5: Regulatory Burden and Administrative Delays in Uganda

\begin{tabular}{|c|c|c|c|c|c|c|c|}
\hline Dimension & $\begin{array}{c}5 \\
5 \\
5 \\
5 \\
5\end{array}$ & $\begin{array}{l}\text { s. } \\
\text { కే }\end{array}$ & 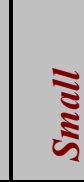 & $\frac{\sqrt{1}}{3}$ & 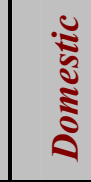 & 㐫 & | \\
\hline $\begin{array}{l}\text { Interpretations of regulations consistent, predictable } \\
(\% \text { disagreeing) }\end{array}$ & 40.0 & 33.3 & 41.0 & 36.4 & 41.0 & 31.1 & 41.4 \\
\hline $\begin{array}{l}\text { Percent senior management's time spent dealing } \\
\text { with regulations }\end{array}$ & 0.04 & 0.07 & 0.04 & 0.06 & 0.04 & 0.05 & 0.04 \\
\hline $\begin{array}{l}\text { Percent revenues typically paid to officials to "get } \\
\text { things done" }\end{array}$ & 2.4 & 1.1 & 2.6 & 3.9 & 1.9 & 3.0 & 2.3 \\
\hline $\begin{array}{l}\text { Percent total firm revenues typically reported for tax } \\
\text { purposes }\end{array}$ & 76.7 & 87.3 & 75.2 & 81.3 & 75.3 & 86.1 & 74.7 \\
\hline \multicolumn{8}{|l|}{ Inspections } \\
\hline $\begin{array}{l}\text { Total days spent in inspections or required meetings } \\
\text { with officials (days) }\end{array}$ & 13.4 & 25.6 & 11.8 & 26.0 & 9.7 & 18.2 & 12.6 \\
\hline Percent of meetings/inspections by local authorities & 19.4 & 7.6 & 21.4 & 8.9 & 23.0 & 16.3 & 20.1 \\
\hline Total cost of fines or seized goods ( $\%$ of sales) & 0.1 & 0.3 & 0.0 & 0.2 & 0.0 & 0.2 & 0.0 \\
\hline $\begin{array}{l}\text { Percent of interactions in which informal payment } \\
\text { requested }\end{array}$ & 6.7 & 9.4 & 6.3 & 6.8 & 6.7 & 7.3 & 6.6 \\
\hline If yes, value? ( $\%$ of sales) & 0.3 & 0.6 & 0.3 & 0.4 & 0.3 & 0.4 & 0.3 \\
\hline \multicolumn{8}{|l|}{ Imports } \\
\hline Avg. days to clear customs (days) & 5.8 & 5.5 & 5.9 & 5.6 & 6.1 & 5.3 & 6.0 \\
\hline Longest delay to clear customs (days) & 11.2 & 10.1 & 11.5 & 12.5 & 9.8 & 10.9 & 11.3 \\
\hline \multicolumn{8}{|l|}{ Exports } \\
\hline Avg. days to clear customs (days) & 3.5 & 4.2 & 3.2 & 3.5 & 3.6 & 3.3 & 3.7 \\
\hline Longest delay to clear customs (days) & 6.0 & 6.3 & 5.9 & 6.5 & 4.8 & 5.8 & 6.2 \\
\hline
\end{tabular}

Source: World Bank (2004) 
Despite the constraints in the operating environment described above, our data indicate that foreign firms make a substantial contribution to the African private sector. Foreign firms invest a greater share of profits back into the firm than local firms. They report a higher percentage of revenue for tax purposes than do domestic firms. Firms with foreign equity are also substantially larger than local firms. Within the sample, the average foreign firm employs 391 workers versus 102, and this disparity held for each country, with Uganda showing a nearly 10 to one ratio (see Figure 3 ). It is clear from these data that foreign firms are a very significant source of employment in Africa.

Figure 3: Firm size

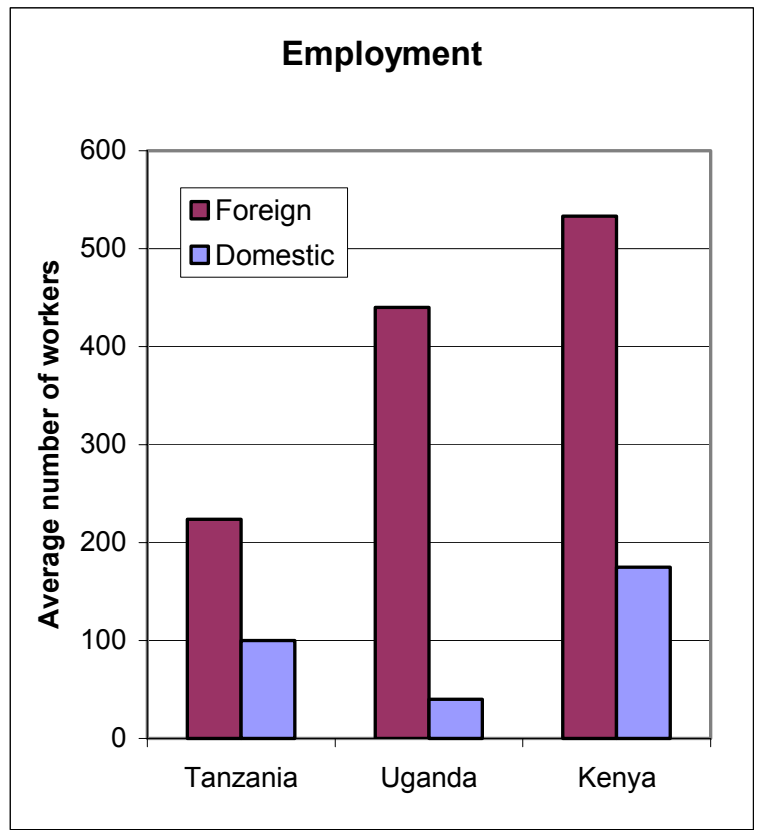

Source: RPED
Figure 4: Productivity

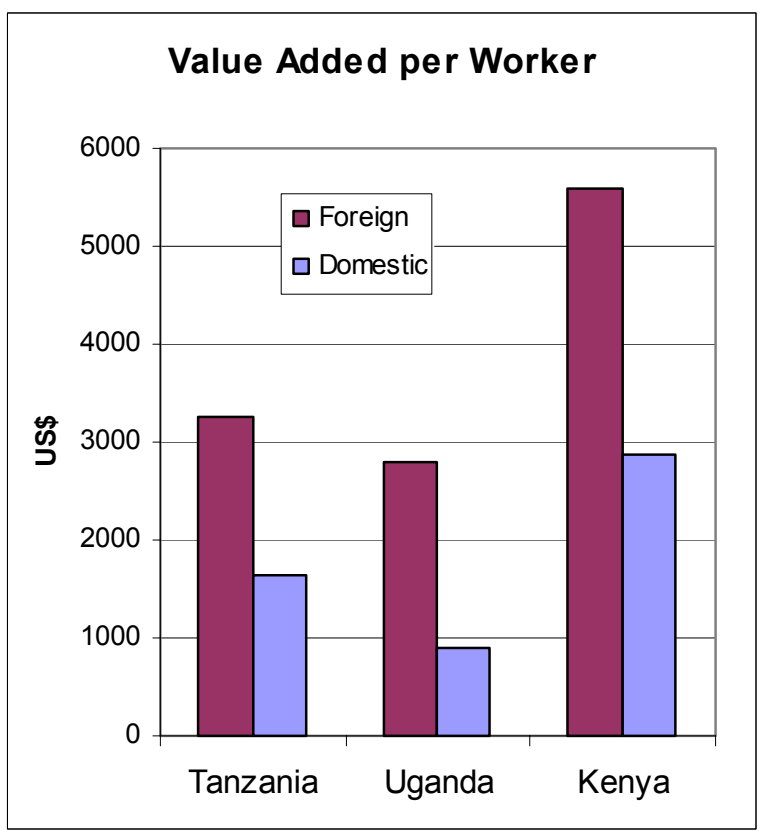

Source: RPED

Foreign firms also report higher productivity; value added per worker is significantly higher in foreign versus local firms (Figure 4). This may be explained by the greater managerial skills and experience in foreign firms (Figure 5). More than half of the foreign firms reported the general manager had a university degree, but this was true in less than onequarter of domestic firms. The manager also reported an average of 11 years' experience in foreign firms versus seven in a domestic firm, although this did not show up in Kenya. This result on management skills is also potentially relevant to spillover effects as since others have found that experience in foreign firms is associated with higher productivity in new local firms started by managers after leaving the foreign firm (World Bank, 2004 on Uganda; Görg and Strobl, 2004 on Ghana). 
Figure 5: Management Skills

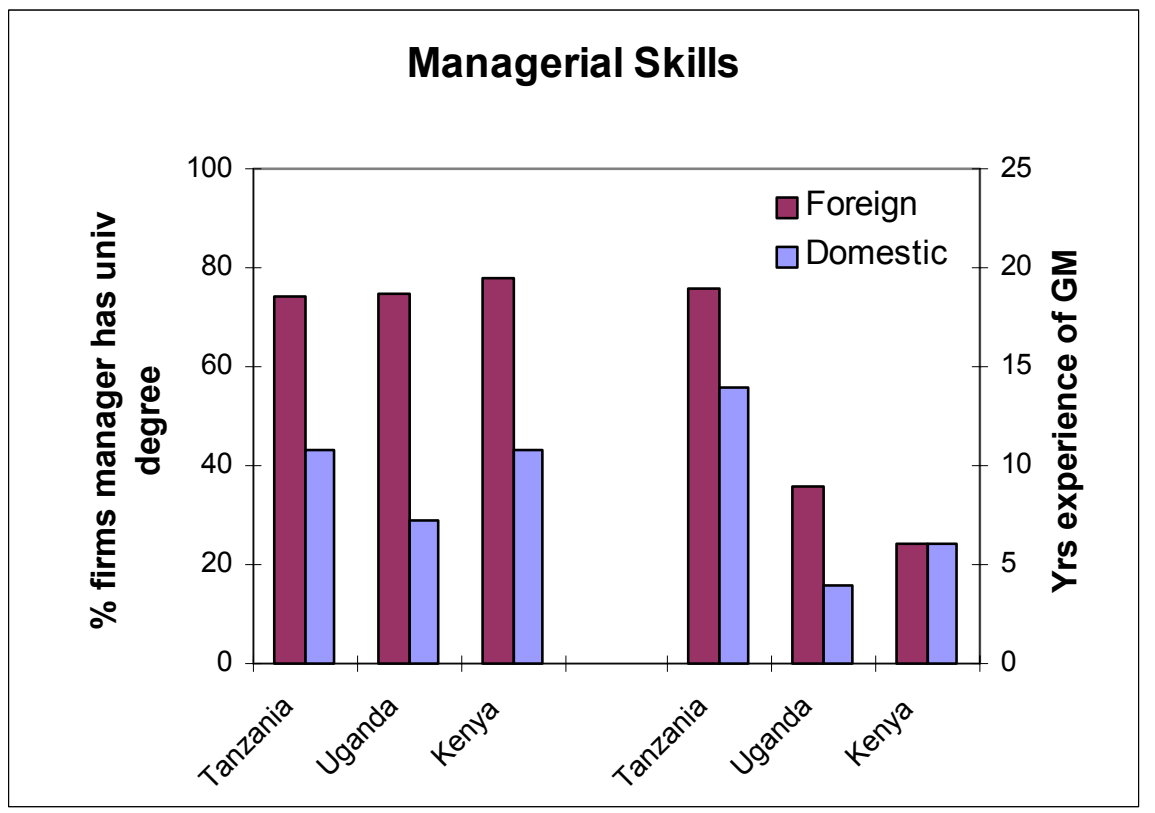

Source: RPED

Worker training may also be a factor. Foreign firms are nearly twice as likely to have a formal training program (Figure 6). Investments in training have been shown to produce large gains for African manufacturing (Biggs et al, 1995). For firms and the economy as a whole, this adds to human capital, productivity, and output. For individual workers, training adds to their skills. This not only offers a reason why these firms might have higher productivity, but also challenges the notion that foreign firms do not invest in their workers. Combined with the finding that foreign subsidiaries are on average three years older than local firms, this does not suggest mobile FDI associated with exploiting short-term low-cost labor.

Figure 6: Formal Worker Training

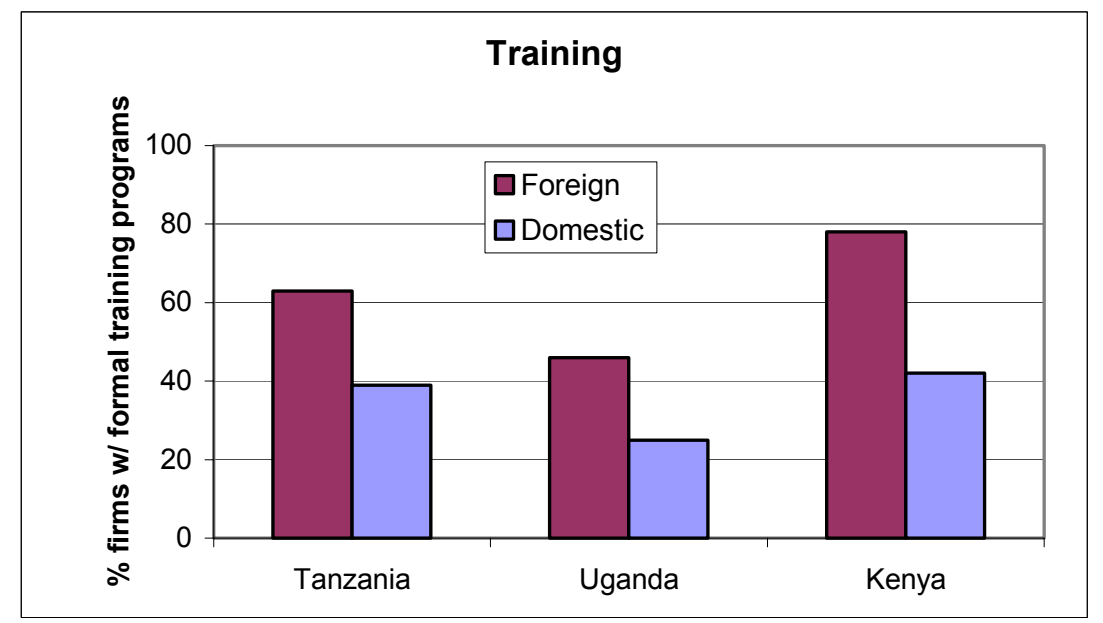

Source: RPED 
The results for the likelihood of exporting are also quite different between foreign and domestic firms. Foreign firms are much more likely to export their output and be able to purchase necessary imported inputs (Figure 7). This suggests that foreign firms are more connected to global markets. The results also show that foreign firms, although they report importing on average 56 percent of their inputs, rely on domestic suppliers for the other 44 percent. This suggests substantial linkage to the local economy although, as one might expect, to a lesser degree than local firms.

\section{Figure 7: Firm Exports and Imports}

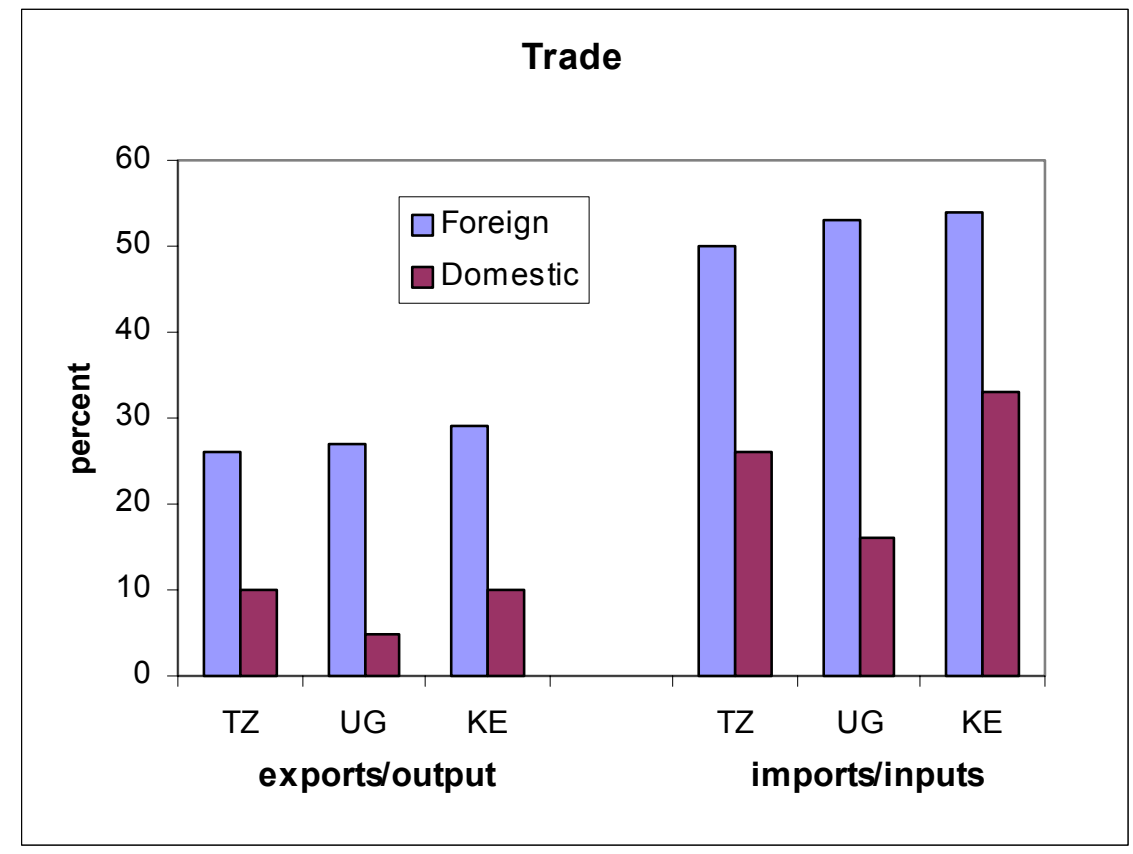

Source: RPED

The survey also highlights foreign-domestic differences in their investments in infrastructure (Figure 8). Eighty percent of foreign firms report owning their own generator, compared with less than half of local firms. Foreign firms were also nearly twice as likely to have their own well or to have built their own roads. Within each country, these patterns held, except for the case of roads in Tanzania, where domestic firms were more likely (11 percent versus 9 percent). These investments in infrastructure suggest three implications. First, this could be viewed as a positive sign that companies are investing for the long-term and are contributing to the country's infrastructure development. Second, this confirms that foreign firms find the general business environment a significant barrier to operation. Lastly, the greater relative investment also suggests that foreign firms are better capitalized to overcome these deficiencies than local firms. 
Figure 8: Infrastructure Investment by Private Firms

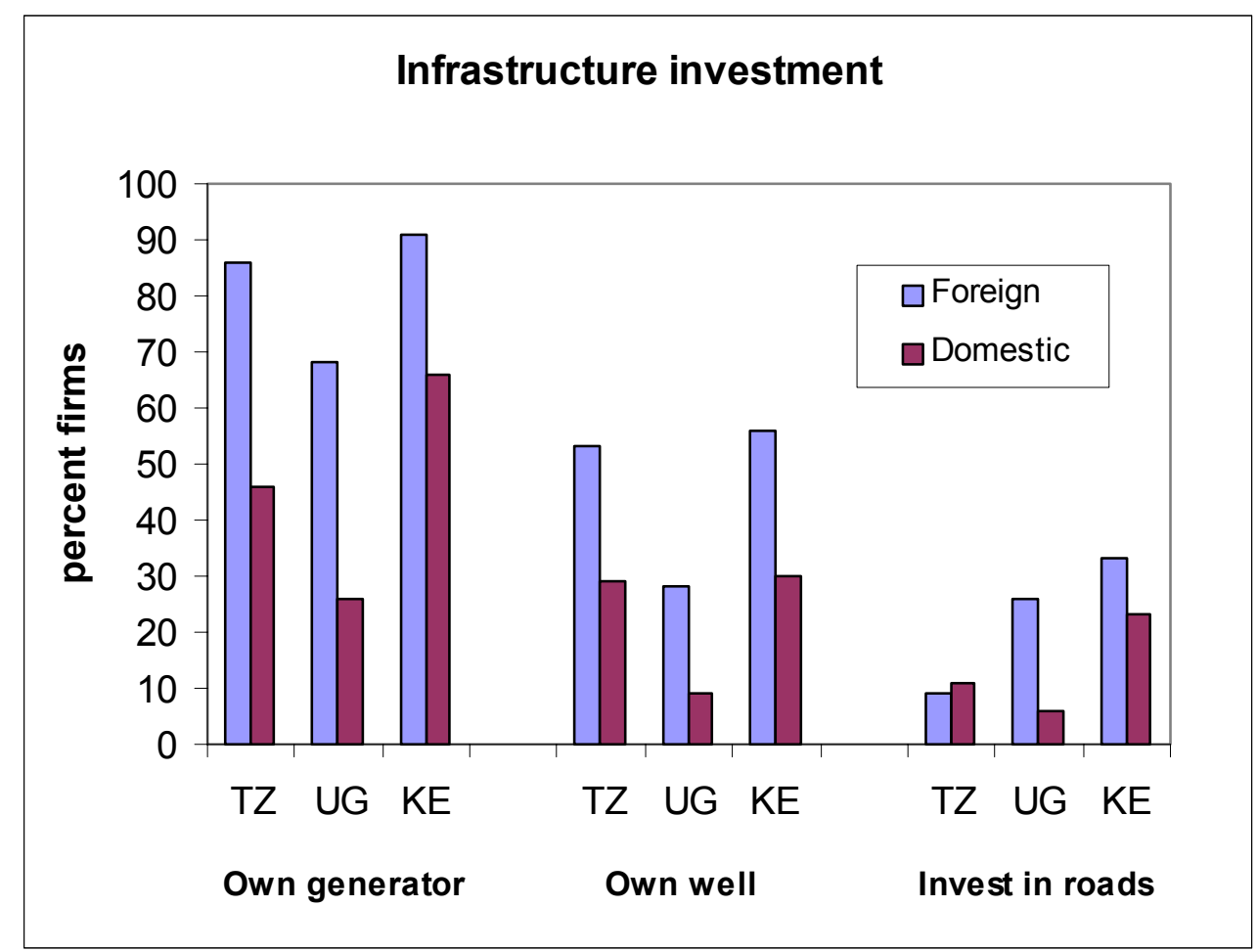

Source: RPED

Finally, it is interesting to note the differences between foreign and local firms with respect to health benefits (Table 6). Foreign firms are three times more likely to provide health insurance in Uganda and almost twice as likely to do so in Tanzania. Similarly, the provision of on-site medical care is much higher in all three countries as is accident compensation or insurance. Foreign firms are also more likely to carry out pre-employment health checks than local firms.

Table 6: Health Benefits: Foreign vs. Local firms

Percentage of firms providing benefits:

\begin{tabular}{|l|l|l|l|l|l|l|}
\hline & \multicolumn{2}{l|}{ Uganda } & \multicolumn{2}{l|}{ Kenya } & \multicolumn{2}{l|}{ Tanzania } \\
\hline & Local & Foreign & Local & Foreign & Local & Foreign \\
\hline Health insurance & $11.1 \%$ & $37.5 \%$ & $45.2 \%$ & $64.8 \%$ & $24.8 \%$ & $42.8 \%$ \\
\hline Med. care at company clinic & $14.8 \%$ & $59.3 \%$ & $29.5 \%$ & $62.2 \%$ & $22.5 \%$ & $48.2 \%$ \\
\hline Accident comp/insur & $23.5 \%$ & $93.8 \%$ & $90.4 \%$ & $83.8 \%$ & $62.3 \%$ & $73.7 \%$ \\
\hline Other health/med benefit & $15.4 \%$ & $21.9 \%$ & $40.4 \%$ & $40.5 \%$ & $41.8 \%$ & $50.0 \%$ \\
\hline Pre-employment check & $17.3 \%$ & $34.4 \%$ & $29.5 \%$ & $48.6 \%$ & $47.1 \%$ & $69.6 \%$ \\
\hline
\end{tabular}




\section{Factors Determining Foreign Ownership: A Simple Econometric Test}

The discussion thus far has examined the constraints to foreign investment in Africa and the differences in the behavior of foreign versus local firms. Key problems in political attitude and pressures, weak infrastructure, and unfavorable business environment deter foreign firms from locating within Sub-Saharan Africa. For firms that have chosen to locate there, we see that they invest more in local infrastructure, are more likely to train their workers, and are larger and more capital intensive than local enterprises. They also tend to have higher market power: they control a greater percentage of the local market for their products compared to local enterprises.

In this section we examine the economic factors distinguishing foreign firms from local enterprises within a simple econometric framework. Any firm's decision to operate is governed by its potential profit; foreign firms that choose to locate in Sub-Saharan Africa do so because they expect that despite the structural constraints, revenues from operations will exceed their costs. By definition,

Profit $=\left(P^{*} Q-C^{*} Q\right)$ where $P=$ unit price, $Q=$ quantity, $C=$ unit cost

Higher profits can be achieved by raising $\mathrm{P}$ through oligopolistic or monopolistic behavior, and/or by lowering cost $\mathrm{C}$ through greater efficiency. A common economic criticism of foreign firms has been that they enter the local markets to drive out competitors, raising prices and exploiting local resources. Others have argued that these firms are more efficient than the locals, and improve the competitive environment in their host countries.

Using our East African data, we test the following hypotheses:

- Hypothesis I: Foreign firms exercise strong market power by creating local monopolies and crowding out domestic investment - i.e. the "economy will be in the hands of foreigners". This hypothesis is tested in our model by using a measure of market share.

- Hypothesis II: Foreign firms are profitable because they are more productive. This is measured by labor productivity, VA/L, managerial education, and worker training variables.

- Hypothesis III: An additional hypothesis that is tested. Some argue that FDI is a drain on foreign exchange, because foreign firms are more likely to use imported raw materials. We test this by including the percentage of raw materials imported in our model. We also include the percentage of output exported.

The model used is a Probit, measuring the likelihood of a firm being a foreign enterprise. We try two specifications for the left hand side variable - the first examines the distinguishing characteristics between foreign and local firms, where foreign firms are defined as those which have any foreign equity. In the second specification, we define 
foreign firms as only those with majority foreign equity-i.e. where foreign equity is greater than 50 percent.

The explanatory variables in our econometric model include the following:

Lwork: Log of total workers employed by the firm (capturing the firm size effect)

Mktsh: Percentage of industry output for the product that is supplied by the firm

Pctexp: Percentage of total output exported

Pctimp: Percentage of total raw materials imported

Unived: A 1/0 dummy, 1 if the manager has a university degree

Train: A 1/0 dummy, 1 if the firm has a training program for its workers

LVal: Log of Value Added per worker, measuring labor productivity

Kenya: Country dummy for Kenya, Uganda is the excluded category

Tanzan: Country dummy for Tanzania; Uganda is the excluded category

The dependent variable a 0/1 variable that is set to 1 in Model 1 if the firm has any foreign equity and is set to 1 in Model 2 if the firm has more than 50 percent foreign equity. The results are presented below:

Table 7: Probit Results on Foreign Ownership

\begin{tabular}{|l|l|l|}
\hline Variable & $\begin{array}{l}\text { Model 1 } \\
(\text { Fgn if equity }>0)\end{array}$ & $\begin{array}{l}\text { Model II } \\
(\text { Fgn if equity }>50)\end{array}$ \\
\hline Intercept & $-3.2^{*}$ & $-3.16^{*}$ \\
& $(0.55)$ & $(0.58)$ \\
\hline Lwork & $0.25^{*}$ & $0.18^{*}$ \\
& $(0.08)$ & $(0.08)$ \\
\hline Tanzan & -0.21 & -0.31 \\
& $(0.25)$ & $(0.26)$ \\
\hline Kenya & $-0.68^{*}$ & $-0.76^{*}$ \\
& $(0.24)$ & $(0.25)$ \\
\hline Pctexp & $0.006^{*}$ & $0.007^{*}$ \\
& $(0.003)$ & $(0.003)$ \\
\hline Pctimp & 0.001 & 0.004 \\
& $(0.002)$ & $(0.003)$ \\
\hline Mktsh & 0.004 & 0.003 \\
& $(0.003)$ & $(0.003)$ \\
\hline Train & 0.14 & 0.11 \\
& $(0.21)$ & $(0.22)$ \\
\hline Unived & 0.28 & 0.32 \\
& $(0.21)$ & $(0.22)$ \\
\hline Lval & $0.14^{*}$ & $0.14^{*}$ \\
& $(0.06)$ & $(0.07)$ \\
\hline $\mathrm{N}$ & 301 & 301 \\
\hline
\end{tabular}


As expected, we see that foreign firms are significantly larger than local enterprises. After controlling for firm size, we see that the two other key factors distinguishing foreign firms from locals are percentage exported and labor productivity. Foreign firms, even within the same size class, are more likely to export their products than local firms (hence bringing in foreign exchange; the import dummy is insignificant) and have a more productive labor force indicating greater efficiency. The market share variable is not significant, indicating that market power is not the key driving force for greater profits for these firms. Thus, we reject Hypotheses I and III, but cannot reject Hypothesis II that foreign firms have higher productivity.

\section{Conclusion}

Foreign investment can play an important role in developing countries. African countries have, for the most part, not received much FDI. At least part of this poor performance is owing to deep-seated sentiments against foreign capital reinforced by political factors that militate against FDI. These factors have manifested themselves in many ways, including a range of business environment factors that impede greater foreign flows. Although much of the ideological resistance has faded, a number of specific challenges to the purported benefits of FDI have been successful in preventing more active liberalization and in moving to deal with indirect barriers. Data from firm surveys in Kenya, Tanzania, and Uganda suggest that there are important positive effects from FDI for both the host economies and the workers in foreign-owned firms. Based on our three-country sample, foreign firms are more productive, bring management skills, invest more heavily in infrastructure and in the training and health of their workers, and are more connected to global markets. At the same time, they do not appear to succeed by grabbing market share and crowding out local industry. These results suggest that many of the objections to foreign investment are exaggerated or false. Africa, by not attracting more FDI, is therefore failing to fully benefit from the potential of foreign capital to contribute to economic development and integration with the global economy. 


\section{References}

ActionAid (2003). "Unlimited Companies: The Developmental Impacts of an Investment Agreement at the WTO," June.

Adedeji, Adebayo (ed.) (1981). Indigenization of African Economies. London: Hutchinson University Library for Africa.

Afrobarometer (2003). "Attitudes to Democracy and Markets in Tanzania, March-April and August 2001," data prepared by Wonbin Cho and Virginia Parish, Michigan State University, August.

Asiedu, Elizabeth (2003a). "Foreign Direct Investment to Africa: The Role of Government Policy, Governance and Political Instability," Mimeo, Department of Economics, University of Kansas.

Asiedu, Elizabeth (2003b). "Policy Reform and Foreign Direct Investment to Africa: Absolute Progress but Relative Decline," Mimeo, University of Kansas, forthcoming in Development Policy Review.

Asiedu, Elizabeth (2001). "On the Determinants of Foreign Direct Investment to Developing Countries: Is Africa Different?" Mimeo, University of Kansas, forthcoming in World Development.

Basu, Anupam and Krishna Srinivasan (2002). "Foreign Direct Investment in Africa - Some Case Studies," IMF Working Paper WP/02/61.

Bates, Robert (1981). Markets and States in Tropical Africa: The Political Basis of Agricultural Policies, University of California Press, Berkeley.

Biggs, Tyler, Manju Shah and Pradeep Srivastava (1995). "Training and Productivity in African Manufacturing Enterprises," Regional Program on Enterprise Development Discussion Paper 15101.

Blomström, Magnus and Ari Kokko (1998) "Multinational corporations and spillovers," Journal of Economic Surveys, 12, 247-77.

Blomström, Magnus and Ari Kokko (1997). "How Foreign Investment Affects Host Countries," Policy Research Working Paper WPS 1745, World Bank.

Boone, Catherine (1993). "Commerce in Cote d'Ivoire: Ivoirianisation without Ivoirian Traders," Journal of Modern African Studies, 31(1), 67-92.

Brautigam, Deborah (2003). "Close Encounters: Chinese Business Networks as Industrial Catalysts in Sub-Saharan Africa," African Affairs, 102, 447-467.

Brennan, James R. (1999). "South Asian Nationalism in an East African Context: The Case of Tanganyika, 1914-1956," Comparative Studies of South Asia, Africa and the Middle East, 19(2), 24-38.

Chabal, Patrick and Jean-Pascal Daloz (1999). Africa Works: Disorder As Political Instrument, Indiana University Press, Bloomington.

Chudnovsky, Daniel and Andres Lopez (2002). "Globalization and Developing Countries:

Foreign Direct Investment, Growth and Sustainable Human Development," UNCTAD Occasional Paper.

Craig, John (2002). "Privatisation and Indigenous Ownership: Evidence from Africa," Working Paper 13, Centre on Regulation and Competition, University of Manchester, January. 
Daniel, John, Varusha Naidoo and Sanusha Naidu (2003). "Post-Apartheid South Africa's Corporate Expansion into Africa," Traders: African Business Journal, AugustNovember, Issue 15.

Dunning, John. (1993), Multinational Enterprises and the Global Economy, Addison-Wesley, Wokingham.

Eric Kolodner (1994) Transnational Corporations: Impediments or Catalysts of Social Development? United Nations Research Institute for Social Development, Occasional Paper No. 5, World Summit for Social Development

Goldsborough, D., et al. (1996). "Reinvigorating Growth in Developing Countries: Lessons from Adjustment Policies in Eight Economies," IMF Occasional Paper 139.

Gordon, David (1993). "Debt, Conditionality, And Reform: The International Relations of Economic Restructuring In Sub-Saharan Africa," in Thomas Callaghy and John Ravenhill, Hemmed In: Responses to Africa's Economic Decline, Columbia University Press, New York, pp. 90-129.

Görg, Holger and Eric Strobl (2004). "Spillovers from foreign firms through worker mobility: An empirical investigation," Mimeo, January.

Grabel, Ilene 1995). "Marketing the Third World: the Contradictions of Portfolio Investment in the Global Economy," World Development, vol. 24, no. 11, November, pp. 1761-1776.

Graham, Edward (2000). Fighting the Wrong Enemy: Antiglobal Activists and Multinational Enterprises, Institute for International Economics, Washington DC, September.

Himbara, David (1993). "Myths and Realities of Kenyan Capitalism," Journal of Modern African Studies, 31(1), 93-107.

Himbara, David (1994). "The Failed Africanization of Commerce and Industry in Kenya," World Development, 22 (3), pp. 469-482.

Hochschild, Adam (1999). King Leopold's Ghost, Houghton Mifflin.

Holmquist, Frank (2002). "Business and Politics in Kenya in the 1990s," Centre of African Studies Occasional Paper, University of Copenhagen.

Jaffee, Steven (1992). "How Private Enterprise Organized Agricultural Markets in Kenya," Policy Research Working Paper WPS 823, World Bank.

Kaunda, Kenneth, Adebayo Adedeji and O.R. Tambo (1979). Africa's Economic Independence, Lusaka, Zambia.

Kobrin, Stephen (1984). "Expropriations as an Attempt to Control Foreign Firms in LDCs: Trends from 1960 to 1979," International Studies Quarterly, 28(3), 329-348.

Kotkin, Joel (1994). Tribes: How Race, Religion and Identity Determine Success in the New Global Economy, Random House.

Lewis, Peter (1996). "From Prebendalism to Predation: The Political Economy of Decline in Nigeria," Journal of Modern African Studies, 34-1, March.

Leys, Colin (1975). Underdevelopment in Kenya: the political economy of neo-colonialism, 1964-71, Heinemann, London.

Markusen, James and Anthony Venables (1997). "Foreign Direct Investment as a Catalyst for Industrial Development." NBER Working Paper No. 6241, Cambridge, MA.

Mengistae, Taye (2001). "Indigenous Ethnicity and Entrepreneurial Success in Africa: Some Evidence from Ethiopia," Policy Research Working Paper WPS 2534, World Bank.

MIGA (2002). Foreign Direct Investment Survey 2002, World Bank, Washington DC. 
Morisset, Jacques (2000). "Foreign Direct Investment in Africa: Policies Also Matter,"

Policy Research Working Paper WPS 2481, World Bank.

Moss, Todd (2003). Adventure Capitalism: Globalization and the Political Economy of Stock Markets in Africa, Palgrave Macmillan, London.

Oxfam (2003a). "The Emperor's New Clothes," Oxfam Briefing Paper 46, April.

Oxfam (2003b). "Running into the Sand," Oxfam briefing paper 53, August.

Pigato, Miria (2001). "The Foreign Direct Investment Environment in Africa," Africa Region Working Paper No. 15, World Bank.

Ramachandran, Vijaya, and Manju Kedia Shah (1997). "The Effects of Foreign Ownership in Africa: Evidence from Ghana, Kenya, and Zimbabwe." RPED Paper 81. World Bank, Washington, DC.

Rodney, Walter (1981). How Europe Underdeveloped Africa, Howard University Press, Washington DC.

Senghaas-Knobloch, Eva (1975). "Internationalization of Capital and the Process of Underdevelopment. The Case of Black Africa," Journal of Peace Research, 12(4), 275-292.

Singh, Harinder and Kwang W. Jun (1995). "Some New Evidence on Determinants of Foreign Direct Investment in Developing Countries," Policy Research Working Paper WPS 1531, World Bank.

South Centre (1997). "Foreign Direct Investment, Development and the New Global Economic Order," Policy Brief.

Sowell, Thomas (1992). Race and Culture: A World View, Pennsylvania State University Press.

Tangri, Roger (1999). The Politics of Patronage in Africa, Africa World Press, Trenton.

Tangri, Roger (1992). "The Politics of Government-Business Relations in Ghana," Journal of Modern African Studies, 30(1), 97-111.

Temu, Andrew and Jean M. Due (1998). "The Success of Newly Privatized Companies: New Evidence from Tanzania," Canadian Journal of Development Studies, 19(2), 315341.

UNCTAD (2002). "Investment Policy Review: The United Republic of Tanzania," United Nations, Geneva.

UNCTAD (2000). "Investment Policy Review: Uganda," United Nations, Geneva.

UNCTAD (1999). National Treatment, United Nations, Geneva.

UNCTAD (1998). World Investment Report 1998: Trends and Determinants, United Nations, Geneva.

Vandenberg, Paul (2003). "Ethnic-sectoral cleavages and economic development: reflections on the second Kenya debate," Journal of Modern African Studies, 41(3), 437-455.

van de Walle, Nicolas (2001). African Economies and the Politics of Permanent Crisis, 1979-99, Cambridge University Press, Cambridge.

Winder, R.B. (1962). "The Lebanese in West Africa," Comparative Studies in Society and History, 4, 296-333.

World Bank (2004) "Competing In The Global Economy: An Investment Climate Assessment For Uganda," Africa Private Sector Group, Feb 22.

WTO (2000), "Trade Policy Reviews, First Press Release: Kenya," Press/TPRB/124, January 19. 


\section{Newspapers}

Business Times (Dar es Salaam)

East African (Nairobi)

Mmegi (Gaborone)

The Monitor (Kampala)

Times of Zambia (Lusaka)

The Nation (Nairobi)

The Post (Lusaka) 